\title{
Editorial: Farewells and Introductions
}

\section{GERRIE F. SNYMAN (UNISA)}

In this issue, Old Testament Essays welcomes Scriber Editorial Systems who will manage and administer the publishing process of the journal for the next three years. The journal also takes leave of Ann Potgieter who administered the journal for the past 14 years as well as Gerda de Villiers who did the language editing the past nine years. As editor, I want to thank Ann and Gerda for their services in making the journal professional and a well-edited text - all efforts that aided the journal to be recognized for the benchmarks it set and a text that one should reckon with. I also want to thank the Old Testament Society of South Africa for appointing me as general editor for a further term. The future of journal publishing remains as murky as ever in the South African context, but the journal will go on and adapt as required. For example, you may notice below behind my name a url with a link to orcid.org.

The presence of predatory journals and conferences as well the curse of plagiarism necessitated a verification process that can safeguard the integrity of a journal. One such method is to provide the possibility to readers to verify the integrity of an author as scholar (apart from the obvious contents provided in the published essays!).

Most of you would have taken note of the NRF now requiring scholars to have an ORCID ID when applying for funding. ORCID ID's are increasingly being used by organizations to confirm identity. An ORCID ID is a 16-character identifier that can be used to clearly identify a specific author - and not another researcher by a similar name - as the author/owner of an academic output or activity. The ORCID ID of a researcher belongs to that researcher or author and not to the institution or company he or she may work for. An ORCID identification enables one to decide what information a person will be associated with and who will be able to see this information. A researcher can keep adding to it throughout his or her research career. An ORCID identifier provides a stable link between all the research activities of the scholar-grant applications, manuscript submissions, publications, entries in institutional repositories and peer review activity. When a researcher needs a curriculum vitae, the ORCID ID provides access to the most recent résumé possible.

From a publisher's side, it has become necessary to identify authors and link articles correctly to them because of metrics and all other measuring instruments. It is also an important instrument to counter plagiarism or article theft.

* To cite: Gerrie F. Snyman, "Editorial: Farewells and Introductions," OTE 30 no. 3 (2017): 569-570. DOI: https://doi.org/10.17159/2312-3621/2017/v30n3a2 
Other benefits are that it enables your article to become more visible and allows you to be credited for peer reviews. When your article is read online, a reader may click on your ORCID ID and land on your list of other publications that may be of interest to him or her. The advantage of this system is that one needs only to update at a single website.

As of 2018, Old Testament Essays will start to implement the ORCID ID system for authors and book reviewers as far as possible. Authors and potential authors, as well as reviewers and potential reviewers are sincerely encouraged to create an ORCID identification.

It is with gratitude that I present OTE 30(3) 2017 to you. The sixteen articles present the reader yet again with a variety of essays from three continents, Europe, Africa as well as Asia on a variety of topics. There are two essays on translation techniques, the one for an ancient text such as the LXX and the other for a bible translation into Shona. There is a review essay on Kilchör's book on Leviticus whereas another author reviews an essay by Ben Zvi on the notion of the empty land, laying bare some fault lines within South African Old Testament Studies. Eco-theology returns as a theme in at least three essays, yet again highlighting the value of Norman Habel's Earth Bible Project. One article looks at the notion of the wilderness in the biblical text, reading it against the grain in order to measure it in terms of core ethical principles in the Bible. A second author enquires into the relationship between humanity and nature in a text of Zephaniah whilst a third author looks at water management in Prov 5. The book of Jeremiah receives attention in two essays: the first looks at the book from a trauma perspective and challenges simplistic understandings of God, and the second essay looks at the issue of prophecy, history and God, suggesting that prophecy and events are caught up in an inescapable loop of sequence and consequence. Poetic biblical literature in general, and psalms in particular, are addressed in three essays. One essay explores honour and shame in Old Testament poetic texts, whereas another uses three psalms to come to an understanding of the reference to "servant" in Is. 61:1. A third author looks at the reception of Psalms within Pentecostal interpretation. There are two essays concerning the book of Genesis. The first one explores the notion of rest in the first creation account and the second essay looks at the presence of the noun "seed" or "offspring" in Genesis. Two articles bring into play nationhood in their understanding of the biblical text. One article utilises the story of Josiah in order to highlight certain leadership qualities he thinks is needed within a Nigerian context whereas the second article looks at the concept of land ownership, the Levites' lack of ownership and the current quest for land in South Africa.

Gerrie Snyman, General Editor, Old Testament Essays. Department of Biblical and Ancient Studies, Unisa. Email: snymagf@unisa.ac.za or ote-editor@otwsaotssa.org.za. ORCID ID: https://orcid.org/0000-0001-5145-2822 